\title{
On the Mechanism of Parathyroid Hormone Stimulation of Calcium Uptake by Mouse Distal Convoluted Tubule Cells
}

Frank A. Gesek and Peter A. Friedman

Department of Pharmacology and Toxicology, Dartmouth Medical School, Hanover, New Hampshire 03755-3835

\begin{abstract}
PTH stimulates transcellular $\mathrm{Ca}^{2+}$ absorption in renal distal convoluted tubules. The effect of PTH on membrane voltage, the ionic basis of the change in voltage, and the relations between voltage and calcium entry were determined on immortalized mouse distal convoluted tubule cells. PTH $\left(10^{-8} \mathrm{M}\right)$ significantly increased ${ }^{45} \mathrm{Ca}^{2+}$ uptake from basal levels of 2.81 \pm 0.16 to $3.88 \pm 0.19$ nmol min ${ }^{-1} \mathrm{mg}$ protein ${ }^{-1}$. PTH-induced ${ }^{45} \mathrm{Ca}^{2+}$ uptake was abolished by the dihydropyridine antagonist, nifedipine $\left(10^{-5} \mathrm{M}\right)$. PTH did not affect ${ }^{22} \mathrm{Na}^{+}$uptake. Intracellular calcium activity $\left(\left[\mathrm{Ca}^{2+}\right]_{i}\right)$ was measured in cells loaded with fura-2. Control $\left[\mathrm{Ca}^{2+}\right]_{i}$ averaged $112 \pm 21 \mathrm{nM}$. PTH increased $\left[\mathrm{Ca}^{2+}\right]_{i}$ over the range of $10^{-11}$ to $10^{-7} \mathrm{M}$. Maximal stimulation to $326 \pm 31 \mathrm{nM}$ was achieved at $10^{-8} \mathrm{M}$ PTH. Resting membrane voltage measured with the potential sensitive dye $\mathrm{DiO}_{6}(3)$ averaged $-71 \pm 2 \mathrm{mV}$. PTH hyperpolarized cells by $19 \pm 4 \mathrm{mV}$. The chloride-channel blocker NPPB prevented PTH-induced hyperpolarization. PTH decreased and NPPB increased intracellular chloride, measured with the fluorescent dye SPQ. Chloride permeability was estimated by measuring the rate of ${ }^{125} \mathrm{I}^{-}$efflux. PTH increased ${ }^{125} \mathrm{I}^{-}$efflux and this effect was blocked by NPPB. Clamping voltage with $\mathrm{K}^{+}$/ valinomycin; depolarizing membrane voltage by reducing extracellular chloride; or addition of NPPB prevented PTH-induced calcium uptake. In conclusion, PTH increases chloride conductance in distal convoluted tubule cells leading to decreased intracellular chloride activity, membrane hyperpolarization, and increased calcium entry through dihydropyridinesensitive calcium channels. (J. Clin. Invest. 1992. 749-758.) Key words: calcium transport $\bullet$ membrane potential $\bullet$ intracellular calcium • ion channels • fluorescence imaging
\end{abstract}

\section{Introduction}

PTH and $1,25(\mathrm{OH})_{2}$ vitamin $\mathrm{D}_{3}$ are the principal physiological regulators of extracellular calcium in humans and other mammals. The major sites at which PTH stimulates renal calcium absorption are cortical thick ascending limbs of Henle's loop (1-4), distal convoluted tubules $(5,6)$ or, in the rabbit, in connecting tubules (7-9). In these hormone-sensitive nephron segments, PTH increases active, transcellular calcium trans-

\footnotetext{
Address correspondence to Peter A. Friedman, Ph.D., Department of Pharmacology and Toxicology, Dartmouth Medical School, 7650 Remsen, Hanover, NH 03755-3835.

Received for publication 13 December 1991 and in revised form 20 April 1992.
}

J. Clin. Invest.

(C) The American Society for Clinical Investigation, Inc. 0021-9738/92/09/0749/10 \$2.00

Volume 90, September 1992, 749-758 port $(3,10-12)$. PTH-induced increases in calcium absorption are associated with a rise of intracellular calcium activity $\left(\left[\mathrm{Ca}^{2+}\right]_{\mathrm{i}}\right)^{1}$ in cortical thick ascending limbs (13) and in connecting tubules (7)

Active absorptive transport across polarized epithelial cells is a two-step process involving entry across apical plasma membranes followed by efflux across basolateral plasma membranes. In a recent study we found that calcium entry in distal convoluted tubule cells is mediated by dihydropyridine-sensitive calcium channels (13). Calcium channels in electrically excitable cells such as cardiac myocytes or skeletal muscle cells are voltage-gated and are activated at depolarizing membrane voltages (14). In some nonexcitable cells hyperpolarization augments agonist-induced calcium influx and depolarization inhibits calcium influx (15-20).

Relatively little information is available regarding the effects of PTH on membrane voltage in any hormone-sensitive cells. Previous studies of the effect of PTH on voltage in target distal nephron segments produced variable results. PTH increased transepithelial voltage in rabbit cortical thick ascending limbs (21) and in rabbit connecting tubules (22), albeit in a biphasic pattern. Significant alterations of voltage in response to PTH in distal nephron segments have not been detected in other studies $(2,4)$. In the present investigation we sought to determine the effects of PTH on membrane voltage, the ionic basis of these effects, and the relations between PTH-induced changes in membrane voltage and calcium uptake in distal convoluted tubule cells. The results show that PTH hyperpolarizes the cell membrane of cultured distal convoluted tubule cells. The time-course of hyperpolarization parallels the change of $\left[\mathrm{Ca}^{2+}\right]_{\mathrm{i}}$ induced by PTH. Evidence is presented indicating that activation of a chloride conductive pathway by PTH is responsible for the voltage effects. Increased chloride conductance in distal convoluted tubule cells results in decreased intracellular chloride activity, membrane hyperpolarization, and increased calcium entry through dihydropyridine-sensitive calcium channels.

\section{Methods}

Procedures for the development of immortalized mouse distal convoluted tubule cells have been described (23-25). Briefly, cortical thick ascending limb and distal convoluted tubule cells were isolated from mice and established in primary cell culture. Transformation was accomplished with chimeric adenovirus 12-simian virus 40 (AD12/ SV40). Clonal cell lines were established by limiting dilution of cells. The cell line so established and used in the present study exhibits: $(a)$ PTH-stimulated adenylyl cyclase and cAMP formation; $(b)$ thiazide-

1. Abbreviations used in this paper: $\left[\mathrm{Ca}^{2+}\right]_{\mathrm{i}}$, intracellular calcium; $\mathrm{DiOC}_{6}(3), 3,3$ 'dihexyloxacarbocyanine iodide; SPQ, 6-methoxy- $N$ (3-sulfopropyl)-quinolinium; NPPB, 5-nitro-2(3-phenylpropyl-amino)benzoic acid. 
sensitive $\mathrm{NaCl}$ cotransport; (c) no effect of bumetanide on sodium or chloride uptake (24). Cell passages 5 to 21 were used in the present study.

Intracellular fluorescence measurements of calcium, voltage, and chloride were performed as previously described in detail $(13,25)$. In brief, cells were grown to near confluence on $25-\mathrm{mm}$ glass cover slips, rinsed three times with KRB (composition below) before a 60 -min incubation with the $\mathrm{Ca}^{2+}$-sensitive indicator fura-2 $\mathrm{AM}\left(10^{-5} \mathrm{M}\right.$; Molecular Probes, Inc., Eugene, $O R$ ), or the voltage-sensitive dye 3,3'dihexyloxacarbocyanine iodide $\left(\operatorname{DiOC}_{6}(3), 10^{-6} \mathrm{M}\right.$, Molecular Probes, Inc.). Intracellular chloride was measured with the $\mathrm{Cl}^{-}$sensitive dye, 6-methoxy- $N$-(3-sulfopropyl)quinolinium (SPQ; Molecular Probes, Inc.). Cells were loaded with SPQ by incubation for $5 \mathrm{~h}$ at a dye concentration of $5 \mathrm{mM}$. All incubations were performed at $37^{\circ} \mathrm{C}$. The cover slips were mounted in a chamber of a microincubation system that was temperature controlled to $37^{\circ} \mathrm{C}$ (MS-C; Narishige USA Inc., Greenvale, NY) and was affixed to the stage of a Nikon Diaphot inverted microscope. Fluorescence excitation and emission intensity were measured with a Nikon Photoscan-2 (Nikon, Inc., Natick, MA). Interference filters of $340 \mathrm{~nm}$ and $380 \mathrm{~nm}$ (Omega Optical, Brattleboro, VT) were used for fura-2 fluorescence excitation while emission at $510 \mathrm{~nm}$ was followed by using a $510-\mathrm{nm}$ dichroic mirror (DM510; Nikon) in series with a $510 \pm 5 \mathrm{~nm}$ interference filter (Omega Optical). Time-controls showed no significant change of intracellular calcium over a period of $120 \mathrm{~min}$. Membrane voltage was measured with $\operatorname{DiOC}_{6}(3)$ at an excitation wavelength of $490 \mathrm{~nm}$ and emission wavelength of $510 \mathrm{~nm}$. Excitation and emission interference filters of 340 $\mathrm{nm}$ and $450 \mathrm{~nm}$, respectively, were used for SPQ fluorescence. In all studies, fields of 2-3 cells on the cover slip were selected by using a shutter assembly mounted in front of the photomultiplier tube. An area devoid of cells on the cover slip was used to measure and subtract background in each experiment; autofluorescence was negligible at the emission wavelengths employed. Background fluorescence after cells were loaded with each of the respective dyes was $<5 \%$ of total fluorescence. Leakage of fura- 2 was negligible over the duration of the experiment. SPQ leakage was 12\%/h $(25,26)$. Recordings of control fluorescence were performed before the addition of hormone or drugs. Fluorescence intensity was sampled at a rate of 1-2 points/s. Absolute values of $\left[\mathrm{Ca}^{2+}\right] \mathrm{i}$ were based on calibrations that were performed as described previously $(13,25)$. Calibration of membrane voltage was performed by a null-point procedure using graded changes in external potassium in the presence of valinomycin (27). Intracellular chloride was calculated by interpolating steady-state SPQ fluorescence intensity under control conditions ( $24 \mathrm{mM}$ ) with that after equilibrating with $\mathrm{KSCN}+$ valinomycin $(140 \mathrm{mM})$, taking dye leak into account $(26)$.

Cellular uptake of ${ }^{22} \mathrm{Na}^{+}$and ${ }^{45} \mathrm{Ca}^{2+}$ was performed as previously reported (25). Nonspecific binding of isotopes to the filters and cells was determined in the presence of $\mathrm{LiCl}$-Hepes (or $\mathrm{Li}_{2} \mathrm{SO}_{4}$-Hepes) buffer added to the cells before addition of labeled ${ }^{22} \mathrm{Na}^{+}$or ${ }^{45} \mathrm{Ca}^{2+}$. A modified KRB was used for cell incubation and isotope transport in ${ }^{45} \mathrm{Ca}^{2+}$ and ${ }^{22} \mathrm{Na}^{+}$uptake and ${ }^{125} \mathrm{I}^{-}$efflux experiments. This buffer contained: $140 \mathrm{mM} \mathrm{NaCl}, 4.6 \mathrm{mM} \mathrm{KCl}, 1 \mathrm{mM} \mathrm{CaCl}, 1 \mathrm{mM} \mathrm{MgCl}$ and was buffered to $\mathrm{pH} 7.40 \pm 0.01$ with $10 \mathrm{mM}$ Hepes and $18 \mathrm{mM}$ Tris base, and adjusted to $295 \pm 2$ mosmol $/ \mathrm{Kg} \mathrm{H}_{2} \mathrm{O}$. Tracer uptakes were linear for $3 \mathrm{~min}$ and in the experiments described in this report were stopped at $1 \mathrm{~min}$. All cellular uptake experiments were normalized for protein content, which was measured by the Lowry method on $50-\mu \mathrm{l}$ aliquots of cells (28). Tracer uptakes are expressed as nanomoles per minute $\times$ milligram protein $\left(\mathrm{nmol} \mathrm{min} \mathrm{mg}^{-1} \mathrm{mg}\right.$ protein $\left.{ }^{-1}\right)$. The rate of ${ }^{125} \mathrm{I}^{-}$efflux was determined as follows. Mouse distal convoluted tubule cells were suspended in KRB and loaded with ${ }^{125} \mathrm{I}^{-}(35 \mu \mathrm{Ci} / \mathrm{ml}$; ICN Biomedicals, Inc., Irvine, CA) for $1 \mathrm{~h}$. Efflux was initiated by transferring the cells to KRB. Efflux was terminated by rapid filtration onto $\mathrm{GF} / \mathrm{C}$ filters (Whatman Inc., Clifton, $\mathrm{NJ}$ ) and rinsing with $\mathrm{Li}_{2} \mathrm{SO}_{4^{-}}$ Hepes buffer. ${ }^{125} \mathrm{I}^{-}$remaining in the cells on filters was counted in a gamma counter ( 8000; Beckman Instruments, Inc., Carlsbad, CA ). An aliquot of cells was retained for normalization of protein content and results are expressed as percentage $(\%){ }^{125}$ I remaining.
Materials. Parathyroid hormone (bovine PTH[1-34]; Sigma Chemical Co., St. Louis MO) or the substituted analogue ( $\mathrm{Nle}^{8,18}$, $\mathrm{Tyr}^{34}$ )-PTH (Bachem Bioscience Inc., Philadelphia, PA), were prepared so that the molar concentration indicated in the figure or text was the final concentration to which cells were exposed. Solutions containing drugs were prepared fresh daily. Chemicals were of the highest grade commercially available. All ${ }^{22} \mathrm{Na}^{+},{ }^{45} \mathrm{Ca}^{2+}$, and ${ }^{125} \mathrm{I}^{-}$uptake or efflux measurements within an experiment were performed in triplicate.

Statistics. Data are presented as means $\pm \mathrm{SE}$, where $n$ indicates the number of separate experiments. $\left[\mathrm{Ca}^{2+}\right]_{i}$, intracellular chloride activity, and membrane voltage were measured in duplicate or triplicate within a single experiment and reported as the mean $\pm \mathrm{SE}$ of $n$ separate experiments. Comparisons between control and drug treatment groups were examined by paired $t$ tests or post hoc analysis of multiple comparisons with Newman-Keuls' tests using the statistical software, ANCOM (SciLab; Guilderland, NY). Values of $P \leq 0.05$ were assumed to be significant.

\section{Results}

PTH effects on calcium and sodium uptake. Control and PTH stimulated rates of calcium and sodium uptake by mouse distal convoluted tubule cells were measured for $1 \mathrm{~min}$ in buffered saline solutions containing $140 \mathrm{mM} \mathrm{Na}^{+}$and $1 \mathrm{mM} \mathrm{Ca}^{2+}$. The results are shown in Table $\mathrm{I}$. Basal calcium uptake averaged $2.81 \pm 0.16 \mathrm{nmol} \mathrm{min}^{-1} \mathrm{mg}$ protein ${ }^{-1}$. After preincubation of the cells for $15 \mathrm{~min}$ with $10^{-8} \mathrm{M}$ PTH, calcium uptake increased by $48 \%$ to $3.88 \pm 0.19 \mathrm{nmol} \mathrm{min} \mathrm{mg}^{-1} \mathrm{mg}$ protein ${ }^{-1}(P$ $<0.01, n=4)$. The 1,4 dihydropyridine calcium channel antagonist, nifedipine $\left(10^{-5} \mathrm{M}\right)$, abolished the PTH-stimulated component of ${ }^{45} \mathrm{Ca}^{2+}$ uptake (Table I). These results support the view that PTH-stimulated calcium entry in mouse distal convoluted tubule cells is mediated by dihydropyridine-sensitive, calcium-permeable channels. Nifedipine had no inhibitory action of its own. This observation suggests that basal rates of calcium entry may be mediated by a mechanism other than by dihydropyridine-sensitive calcium channels.

Sodium uptake averaged $344 \pm 19 \mathrm{nmol} \mathrm{m^{-1 }} \mathrm{mg}$ protein $^{-1}$ and was not affected by incubation with PTH for $15 \mathrm{~min}$ ( Table I). We also measured ${ }^{22} \mathrm{Na}^{+}$uptake after 1,2 , and $5 \mathrm{~min}$ of incubation with PTH and were unable to detect any effect. Thus, PTH specifically stimulates calcium uptake by mouse distal convoluted tubule cells. Furthermore, as shown in Table I, nifedipine had no detectable effect on ${ }^{22} \mathrm{Na}^{+}$uptake suggest-

Table I. Calcium and Sodium Uptake by Mouse Distal Convoluted Tubule Cells

\begin{tabular}{|c|c|c|}
\hline & ${ }^{45} \mathrm{Ca}^{2+}$ Uptake & ${ }^{22} \mathrm{Na}^{+}$Uptake \\
\hline & nmol min $^{-1}$ mg protein ${ }^{-1}$ & nmol min $^{-1}$ mg protein ${ }^{-1}$ \\
\hline Control & $2.81 \pm 0.16$ & $344 \pm 19$ \\
\hline PTH & $3.88 \pm 0.19^{*}$ & $353 \pm 33$ \\
\hline PTH + nifedipine & $2.88 \pm 0.17^{\dagger}$ & $354 \pm 28$ \\
\hline Nifedipine & $2.78 \pm 0.07$ & $343 \pm 16$ \\
\hline$n$ & 4 & 4 \\
\hline
\end{tabular}

1-min rates of ${ }^{45} \mathrm{Ca}^{2+}$ and ${ }^{22} \mathrm{Na}^{+}$uptake were measured as described in Methods. Cells treated with $10^{-8} \mathrm{M}$ PTH were exposed for $15 \mathrm{~min}$ in the presence or absence of $10^{-5} \mathrm{M}$ nifedipine. Values represent means $\pm \mathrm{SE}$ of triplicate measurements performed in the indicated number of experiments. ${ }^{*} P<0.01$ vs. control. ${ }^{\dagger} P<0.01$ vs. PTH. 


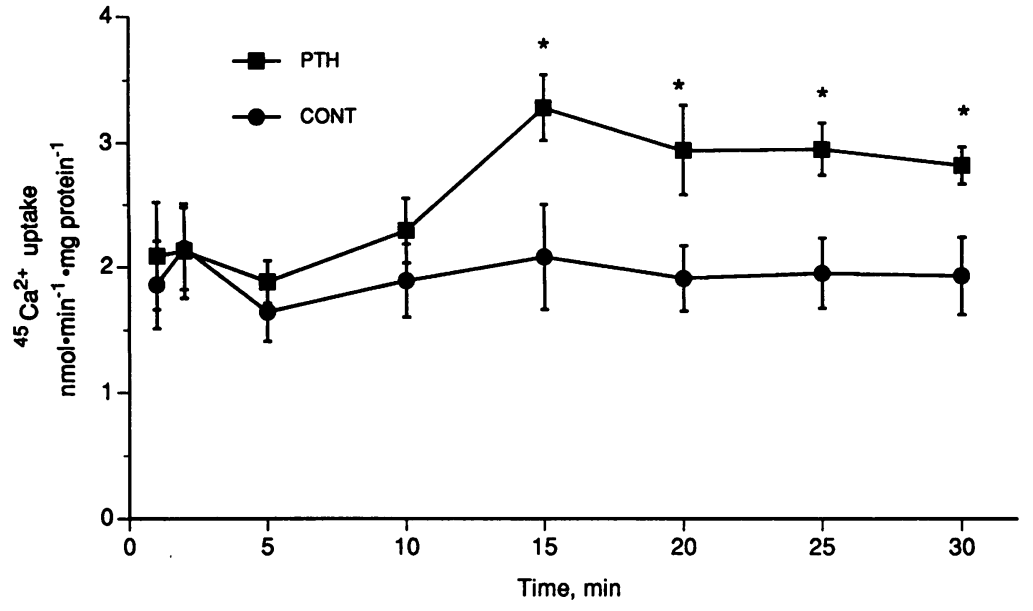

Figure 1. Time-course of PTH-stimulation of ${ }^{45} \mathrm{Ca}^{2+}$ uptake in distal convoluted tubule cells. Cells were pretreated with $10^{-8} \mathrm{M}$ PTH for the times indicated in the figure. ${ }^{45} \mathrm{Ca}^{2+}$ was added for the final minute of incubation. For the 1-min incubation, PTH and ${ }^{45} \mathrm{Ca}^{2+}$ were added simultaneously. ${ }^{45} \mathrm{Ca}^{2+}$ in paired, untreated controls $(C O N T)$ was also measured. Each point represents the mean \pm SE of three observations. ${ }^{*} P<0.01$, compared to control. - - - PTH; - $\bullet-$, control. ing that sodium entry does not proceed through cation channels that are inhibitable by dihydropyridine blockers.

The time-course of ${ }^{45} \mathrm{Ca}^{2+}$ uptake stimulated by PTH in mouse distal convoluted tubule cells is shown in Fig. 1. The results indicate that at least $10 \mathrm{~min}$ elapsed after exposure to $10^{-8} \mathrm{M}$ PTH before a significant increase in the rate of calcium uptake. This latency of PTH action is comparable to that previously reported in isolated, microperfused mouse cortical thick ascending limbs and in mixed primary cell cultures of mouse cortical thick ascending limb and distal convoluted tubule cells (13).

Concentration dependence of PTH action on $\left[\mathrm{Ca}^{2+}\right]_{i}$. Control $\left[\mathrm{Ca}^{2+}\right]_{\mathrm{i}}$ averaged $112 \pm 21 \mathrm{nM}(n=9)$. PTH increases $\left[\mathrm{Ca}^{2+}\right]_{\mathrm{i}}$ in primary cell cultures of distal convoluted tubule and cortical thick limb cells (13). The concentration dependence of PTH action on $\left[\mathrm{Ca}^{2+}\right]_{i}$ in transformed distal convoluted tubule cells was determined in five experiments and the results are illustrated in Fig. 2. PTH evoked incremental elevations of $\left[\mathrm{Ca}^{2+}\right]_{\mathrm{i}}$ with increasing concentrations over the range of $10^{-11}$ to $10^{-7} \mathrm{M}$ PTH. Half-maximal stimulation was achieved at a concentration of $0.2 \mathrm{nM}$. Maximal stimulation occurred at
$10^{-8} \mathrm{M}$ PTH and therefore this concentration was used in the subsequent experiments described in this report. As shown in Table II, nifedipine inhibited the PTH-stimulated rise of $\left[\mathrm{Ca}^{2+}\right]_{\mathrm{i}}$ induced by PTH, but had no effect of its own on $\left[\mathrm{Ca}^{2+}\right]_{\mathrm{i}}$. These results are qualitatively and quantitatively in accord with previous observations and support the view that the cell line employed in the present work maintains these aspects of the distal convoluted tubule phenotype (13).

PTH hyperpolarizes membrane voltage. Cellular calcium entry, whether mediated by voltage-gated or by receptor-operated calcium channels, displays voltage dependence. To determine the effect of PTH on membrane voltage in mouse distal convoluted tubule cells, we used the potential sensitive dye, $\mathrm{DiOC}_{6}(3)$. Results of a representative experiment are shown in Fig. 3. For reference and comparison, a separate recording of $\left[\mathrm{Ca}^{2+}\right]_{i}$ is shown in the upper trace. Both measurements were performed in the presence of $140 \mathrm{mM}$ extracellular $\mathrm{NaCl}$ and 1 $\mathrm{mM} \mathrm{Ca}{ }^{2+}$. Before the addition of PTH, $\left[\mathrm{Ca}^{2+}\right]_{\mathrm{i}}$ was stable and averaged $\sim 100 \mathrm{nM}$. PTH $\left(10^{-8} \mathrm{M}\right)$ was added at $3 \mathrm{~min}$. After a latency of $8 \mathrm{~min},\left[\mathrm{Ca}^{2+}\right]_{\mathrm{i}}$ rose slowly over the next $10 \mathrm{~min}$ after which steady-state levels of $\sim 300 \mathrm{nM}$ were recorded.

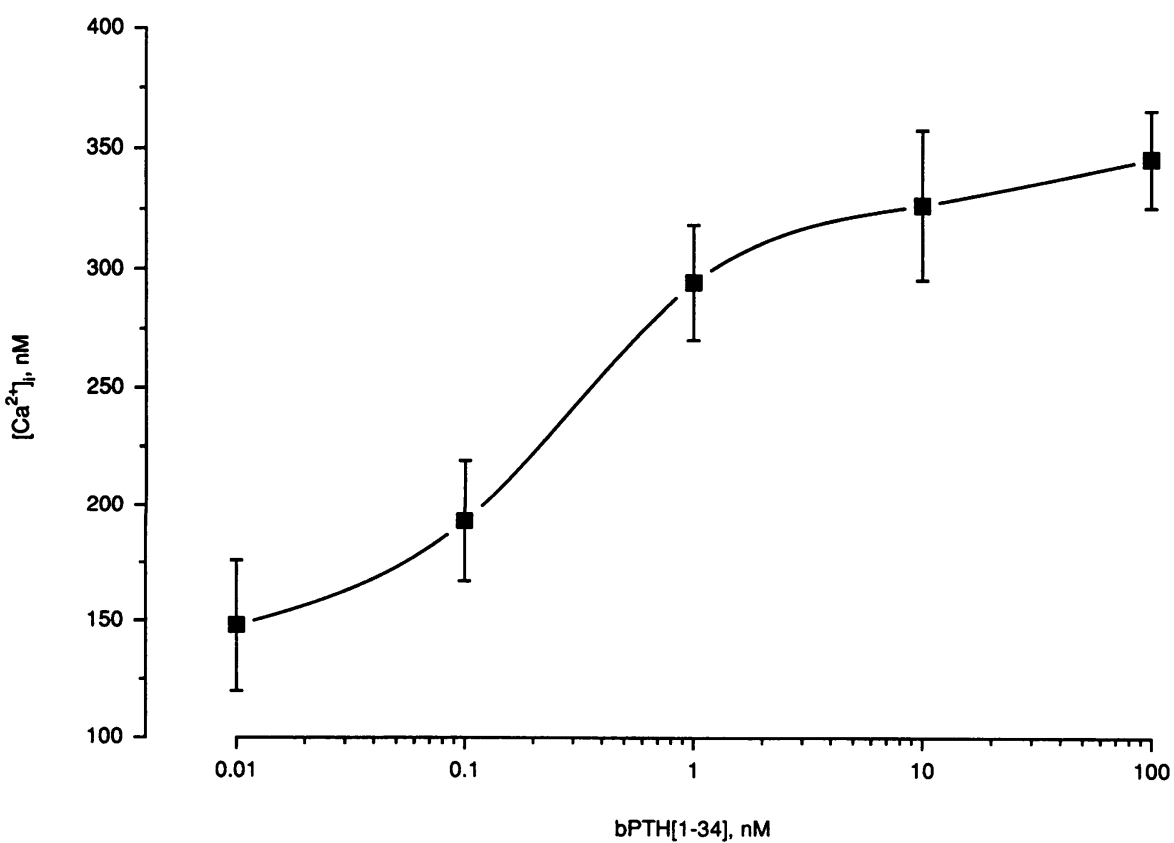

Figure 2. Concentration dependent PTH action on intracellular calcium $\left(\left[\mathrm{Ca}^{2+}\right]_{i}\right)$ in distal convoluted tubule cells. Cells were grown on cover slips and loaded with the calcium-sensitive dye fura- $2 \mathrm{AM}$ as detailed in Methods. At each concentration of PTH, $\left[\mathrm{Ca}^{2+}\right]_{\mathrm{i}}$ was calculated from the average of $300-400$ values after the fluorescent signal had stabilized. Each point represents the mean $\pm \mathrm{SE}$ of five observations. 
Table II. Nifedipine Effects on $\left[\mathrm{Ca}^{2+}\right]_{i}$

\begin{tabular}{lc}
\hline & {$\left[\mathrm{Ca}^{2+}\right]_{\mathrm{i}}$} \\
\hline Control & $n M$ \\
Nifedipine & $115 \pm 8$ \\
Nifedipine + PTH & $119 \pm 10$ \\
$n$ & $122 \pm 6$ \\
& 3 \\
\hline
\end{tabular}

$\left[\mathrm{Ca}^{2+}\right]_{\mathrm{i}}$ was measured in mouse distal convoluted tubule cells as described in Methods and elsewhere $(13,25)$. The protocol was similar to that depicted in Fig. 2. Control measurements were made for 3 min. Nifedipine $\left(10^{-5} \mathrm{M}\right)$ was then added and $\left[\mathrm{Ca}^{2+}\right]_{i}$ was followed for an additional $5 \mathrm{~min}$. PTH $\left(10^{-8} \mathrm{M}\right)$ was added to the incubation chamber and $\left[\mathrm{Ca}^{2+}\right]_{\mathrm{i}}$ was measured for $20 \mathrm{~min}$.

Membrane voltage as reported by $\operatorname{DiOC}_{6}(3)$ is shown in the lower trace. Membrane hyperpolarization is reflected by decreases of fluorescence. Inspection of the voltage response to PTH shows four features. First, there was a delay of $\sim 8 \mathrm{~min}$ before voltage began to hyperpolarize. Second, steady-state voltage was reached after 4-5 additional min, i.e., at 12-13 min after addition of PTH to the perfusion chamber. Third, steadystate levels of membrane voltage were achieved considerably before $\left[\mathrm{Ca}^{2+}\right]_{\mathrm{i}}$ reached plateau values. Fourth, in the continued presence of PTH, both membrane hyperpolarization and increased $\left[\mathrm{Ca}^{2+}\right]_{\mathrm{i}}$ were constant for as long as they were followed. The data in Table III show that the PTH-induced rise of $\left[\mathrm{Ca}^{2+}\right]_{\mathrm{i}}$ exhibited a similar time-course to PTH-induced hyperpolarization. These experiments clearly establish that PTH hyperpolarizes membrane voltage in mouse distal convoluted tubule cells. The calculated resting membrane voltage averaged $-71 \pm 2 \mathrm{mV}(n=10)$. PTH-induced hyperpolarization, calibrated by a null-point procedure, averaged $19 \pm 4 \mathrm{mV}$ (Table IV).

We next inquired into the origin of the membrane hyperpolarization evoked by PTH. Since PTH had no detectable effect on sodium entry, we speculated that an alteration in the cellular chloride diffusion potential may underlie the hyperpolarization caused by PTH. We tested this hypothesis by several independent approaches. In the first set of experiments, we examined the effect of the chloride channel blocker NPPB on PTH-induced hyperpolarization. The data in Table IV show that NPPB abolished the change in voltage stimulated by PTH. These observations are consistent with the view that chloride channels are involved in PTH-induced membrane hyperpolarization. NPPB had no effect of its own membrane voltage. We also examined the effect of nifedipine alone and in combination with PTH. These data, shown in Table IV, failed to reveal any inhibitory action of nifedipine on voltage. Thus, calcium influx stimulated by PTH does not contribute to membrane

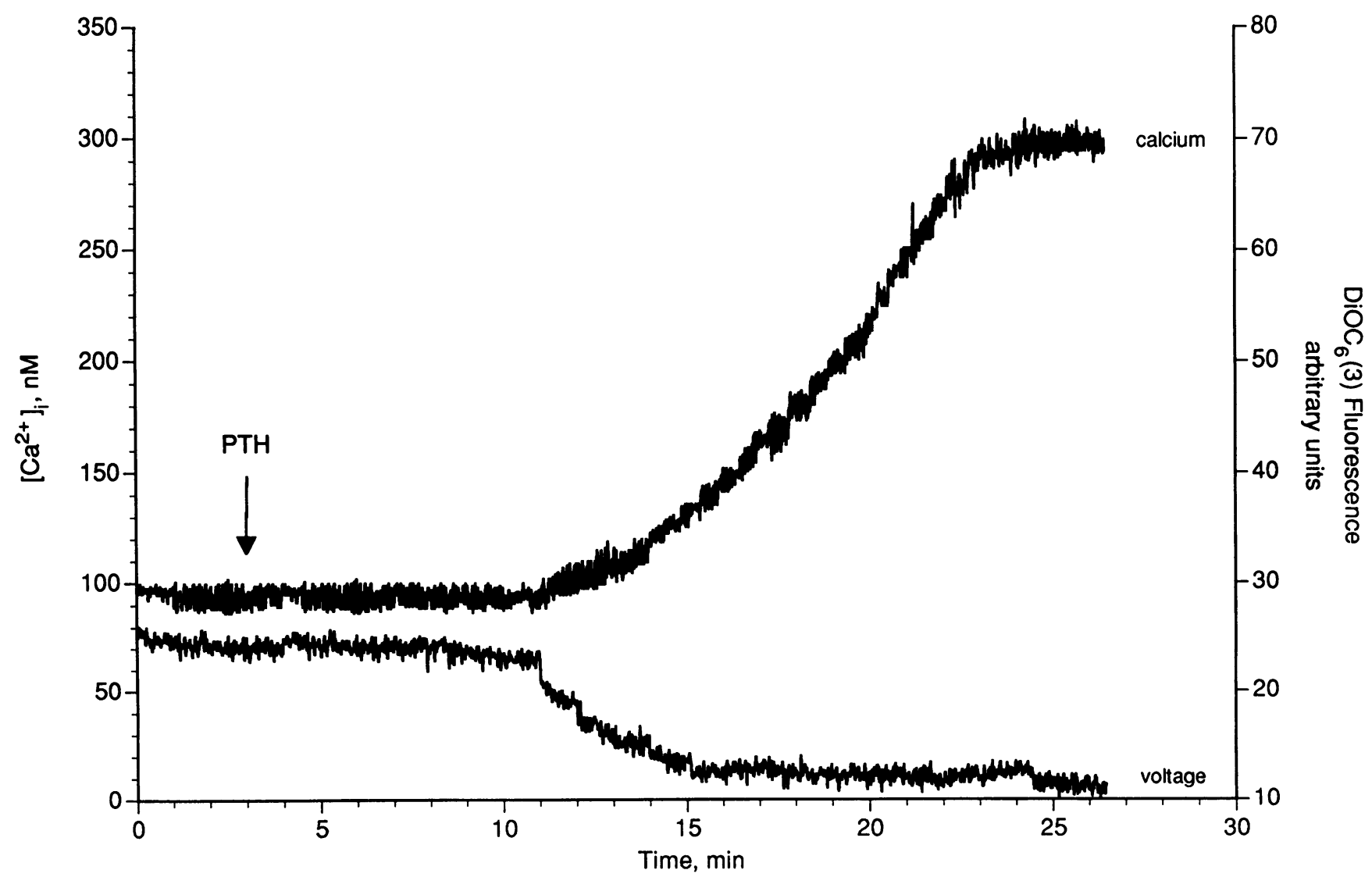

Figure 3. PTH effects on intracellular calcium $\left(\left[\mathrm{Ca}^{2+}\right]_{\mathrm{i}}\right)$ and voltage in mouse distal convoluted tubule cells. Cells were grown on cover slips and loaded with the calcium-sensitive dye, fura- $2 \mathrm{AM}$ or with the potential-sensitive dye, 3,3'-dihexyloxacarbocyanine iodide ( $\left.\mathrm{DiOC}_{6}[3]\right)$. The upper trace and left-hand ordinate show the results of a representative experiment in which the action of PTH on $\left[\mathrm{Ca}^{2+}\right]_{i}$ was recorded. The lower trace and right-hand ordinate show the effect of $\mathrm{PTH}$ on voltage. Decreases of $\mathrm{DiOC}_{6}(3)$ fluorescence intensity are inversely related to membrane voltage. In each experiment, PTH $\left(10^{-8} \mathrm{M}\right)$ was added at $3 \mathrm{~min}$. These results are typical of a total of four determinations. 
Table III. Time-course of PTH Stimulation of $\left[\mathrm{Ca}^{2+}\right]_{i}$, Voltage and Intracellular Chloride Activity

\begin{tabular}{lccr}
\hline & $\begin{array}{c}\text { Latency } \\
\text { to onset }\end{array}$ & $\begin{array}{c}\text { Time from } \\
\text { onset to } \\
\text { plateau }\end{array}$ \\
\hline & $\min$ & $\min$ & $n$ \\
{$\left[\mathrm{Ca}^{2+}\right]_{\mathrm{i}}$} & $8.4 \pm 1.2$ & $7.3 \pm 0.9$ & 5 \\
$\mathrm{Voltage}$ & $8.1 \pm 0.5$ & $4.2 \pm 0.6$ & 4 \\
{$\left[\mathrm{Cl}^{-}\right]_{\mathrm{i}}$} & $6.0 \pm 0.6^{*}$ & $4.4 \pm 0.5$ & 4 \\
\hline
\end{tabular}

${ }^{*} P<0.05$ vs. voltage.

hyperpolarization. In other words, these observations suggest that entry of extracellular calcium is not required for PTH-induced membrane hyperpolarization.

Effect of PTH on intracellular chloride activity. The observation delineated above suggested that PTH may activate chloride channels with an attendant increase in chloride conductance leading to a decrease of intracellular chloride. Therefore, a second set of experiments was undertaken to determine directly the effects of PTH on intracellular chloride. The results of an experiment in which we measured the effect of PTH on intracellular chloride is shown in Fig. 4. Changes in SPQ fluorescence are inversely related to alterations of intracellular chloride activity. When SPQ fluorescence stabilized, PTH was added to the incubation chamber. After a latency of $\sim 6 \mathrm{~min}$ SPQ fluorescence increased, reaching maximal levels at $\sim 10$ min after PTH addition (Table III). This fall of intracellular chloride activity preceded the change in membrane voltage. These results suggest that the decrease of intracellular chloride is responsible for the hyperpolarization. Fluorescence intensity remained constant until an extensive rinse period was begun. Fluorescence excitation was turned off during this period to avoid photobleaching. By $45 \mathrm{~min}$, intracellular chloride activity returned to control levels. NPPB (plus PTH) was then added to the bath and there was a prompt fall in SPQ fluores-
Table IV. Effects of PTH, NPPB, and Nifedipine on Membrane Voltage

\begin{tabular}{lrcccc}
\hline & PTH & PTH + NPPB & NPPB & PTH + nifedipine & Nifedipine \\
\hline$\Delta \mathrm{mV}$ & 19 & 4.2 & -1.6 & 23 & 1.3 \\
$\mathrm{SE}$ & \pm 4 & \pm 2 & \pm 4 & \pm 7 & \pm 3 \\
$n$ & 3 & 4 & 4 & 3 & 3
\end{tabular}

Changes in membrane voltage $(\Delta \mathrm{mV})$ were measured with the fluorescent dye $\operatorname{DiOC}_{6}(3)$ as described in Methods. Cells were exposed to PTH $\left(10^{-8} \mathrm{M}\right)$ alone or in combination with NPPB $\left(10^{-5} \mathrm{M}\right)$ or nifedipine $\left(10^{-5} \mathrm{M}\right)$. Values represent means $\pm \mathrm{SE}$ for the indicated number $(n)$ of experiments.

cence signaling a profound increase of intracellular chloride activity. After washout of the chloride channel blocker, intracellular chloride activity returned to control levels. Comparable results were observed in four experiments. These observations show that PTH decreases intracellular chloride activity.

Effects of PTH on anion permeability. The results presented thus far are consistent with the view that PTH hyperpolarizes mouse distal convoluted tubule cells secondary to a decrease of intracellular chloride. Since PTH had no discernible effect on sodium uptake (Table I), it is unlikely that Na-coupled chloride entry was diminished. Therefore, to determine if the fall of intracellular chloride was due to an increase in chloride permeability, we tested the effect of PTH on chloride efflux by measuring ${ }^{125}$ I efflux. A similar approach has been used in other transporting epithelia $(29,30)$. Control rates of ${ }^{125}$ I efflux were $\sim 15 \%$ over 5 min. The results depicted in Fig. 5 show that pretreatment of cells with $10^{-8} \mathrm{M}$ PTH significantly increased the rate of ${ }^{125} \mathrm{I}$ efflux compared to controls. NPPB blocked the PTH effect on ${ }^{125}$ I efflux and reduced the rate of ${ }^{125}$ I efflux below control levels. The inset to Fig. 5 compares control and PTH-stimulated rates of ${ }^{125}$ I efflux. PTH pretreatment increased the rate of anion efflux by $128 \%(P<0.01)$. To the extent that ${ }^{125}$ I efflux was blocked by NPPB, these observations

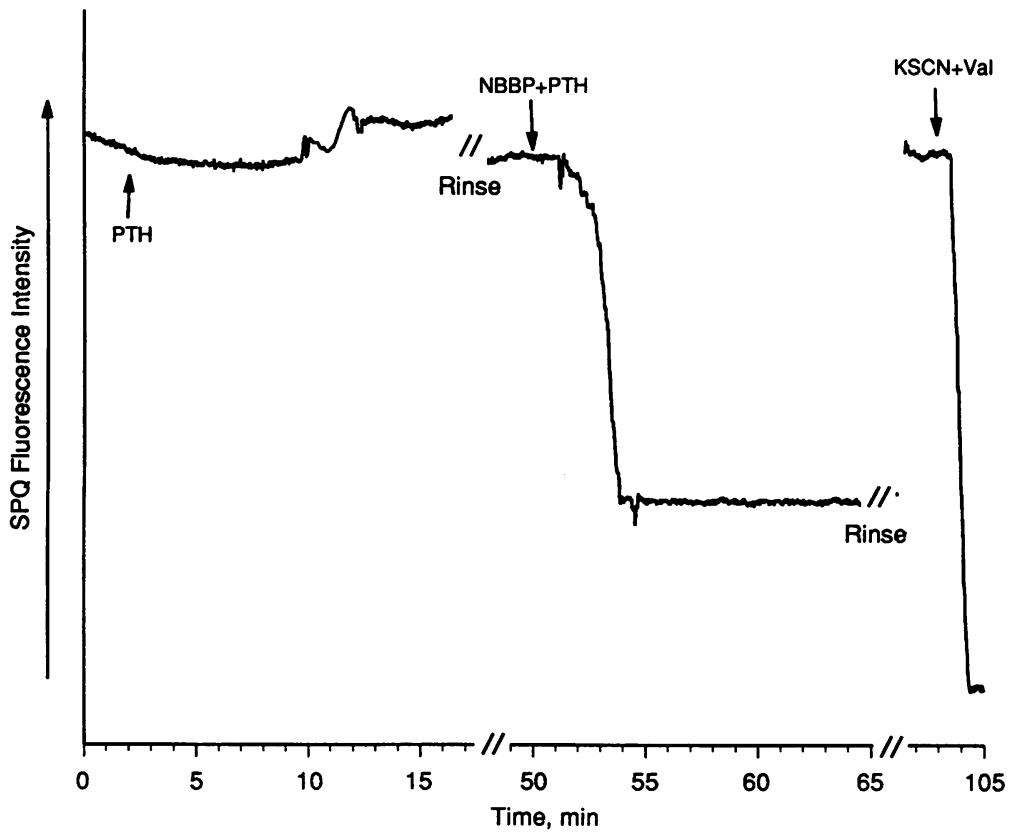

Figure 4. Effect of PTH on intracellular chloride. Representative recording of changes of intracellular $\mathrm{Cl}^{-}$measured in cells grown on a cover slip and loaded with the fluorescent indicator, 6-methoxy- $N$-(sulfopropyl)-quinolinium (SPQ) as described in Methods. Decreases of fluorescence intensity are inversely related to intracellular chloride activity. PTH $\left(10^{-8} \mathrm{M}\right)$ was added to the incubation chamber at $3 \mathrm{~min}$. Recording was turned off during a 32-min rinse period. After the rinse, intracellular chloride had returned to control levels. Application of the $\mathrm{Cl}^{-}$-channel blocker 5-nitro-2(3-phenylpropyl-amino)benzoic acid (NPPB, $10^{-5} \mathrm{M}$ ) + PTH at 50 min resulted in a profound and stable increase of intracellular $\mathrm{Cl}^{-}$. After exchange and washout of bathing solution, intracellular chloride returned to control levels. Cells were then rinsed and $\mathrm{KSCN}(150 \mathrm{mM})+5 \mu \mathrm{M}$ valinomycin was added to quench intracellular SPQ fluorescence. Comparable results were obtained in three additional experiments. 


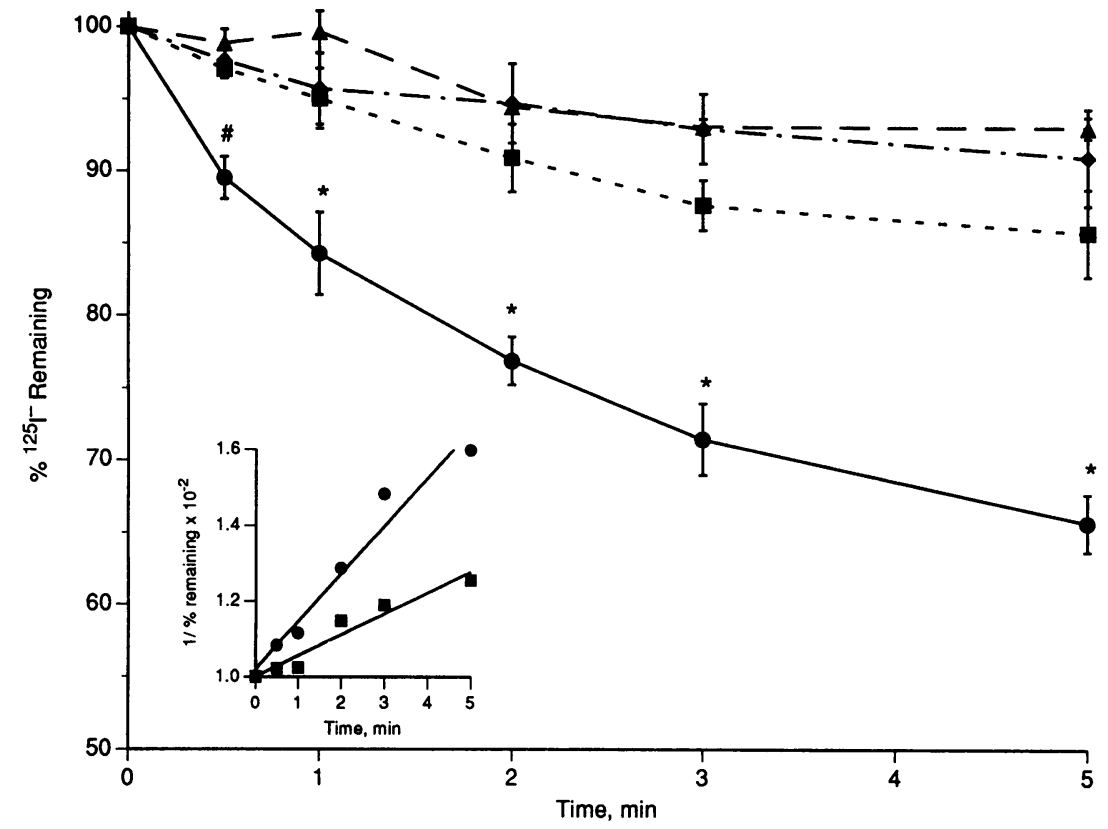

Figure 5. Effects of PTH and chloride channel blockade on ${ }^{125}$ I efflux. Cells were loaded with ${ }^{125} \mathrm{I}^{-}$as described in Methods. PTH $\left(10^{-8} \mathrm{M}\right)$, and/or NPPB $\left(10^{-5} \mathrm{M}\right)$ when added were present for $15 \mathrm{~min}$. Results were normalized for protein content and are expressed as a percentage of the counts remaining at time zero. Average activity for the four groups at time zero was $18,469 \pm 1,005$ $\mathrm{cpm} / \mathrm{mg}$ protein $\triangle, \mathrm{NPPB} ; \bullet, \mathrm{NPPB}+\mathrm{PTH} ; \mathbf{\bullet}$, control; $\bullet$, PTH. Symbols are means \pm SE of triplicate measurements in three separate experiments. The inset shows the results of inverse transformation of the control and PTH-stimulated rates of efflux. For control, $y=5.53 \times 10^{-2} x+1.00, r$ $=0.97$. For PTH pretreated cells, $y=12.61$ $\times 10^{-2} x+1.00, r=0.98$. The two slopes are significantly different $(P<0.01) .{ }^{*} P<0.05,{ }^{*} P$ $<0.01$, compared to control. suggest that PTH activates plasma membrane chloride channels, increases chloride conductance, and enhances chloride efflux in distal convoluted tubule cells. The fact that NPPB, as noted above, had no effect of its own on membrane voltage, whereas it significantly inhibited ${ }^{125}$ I efflux, suggests that under control conditions, i.e., in the absence of PTH, chloride conductance is relatively low compared to that of potassium and/ or the current $\times$ resistance (IR) drop across the cell membrane is too small to detect. Alternatively, PTH may insert or activate chloride channels.

Relationship between membrane voltage and PTH-induced calcium entry. We reasoned that if PTH-induced decreases of intracellular chloride activity are responsible for membrane hyperpolarization and this effect, in turn, increases calcium entry, then NPPB, which abolished the voltage effect, should also block PTH-stimulated increases of calcium entry. The results of experiments in which we tested this hypothesis are shown in Table V. As before, PTH significantly increased both ${ }^{45} \mathrm{Ca}^{2+}$ uptake and $\left[\mathrm{Ca}^{2+}\right]_{i}$. These stimulatory effects of PTH were abolished by NPPB. When added alone, NPPB had no effect.

Table V. PTH and NPPB Effects on ${ }^{45} \mathrm{Ca}^{2+}$ uptake and $\left[\mathrm{Ca}^{2+}\right]_{i}$

\begin{tabular}{lcc}
\hline & ${ }^{45} \mathrm{Ca}^{2+}$ uptake & {$\left[\mathrm{Ca}^{2+}\right]_{\mathrm{i}}$} \\
\hline & $n m o l$ min $^{-1} m g$ protein & \\
& & $n M$ \\
Control & $2.57 \pm 0.16$ & $109 \pm 7$ \\
PTH & $3.80 \pm 0.15^{*}$ & $326 \pm 31^{*}$ \\
NPPB + PTH & $2.65 \pm 0.14^{\dagger}$ & $120 \pm 7^{\dagger}$ \\
NPPB & $2.53 \pm 0.21$ & $105 \pm 13$ \\
$n$ & 3 & 3
\end{tabular}

1-min rates of ${ }^{45} \mathrm{Ca}^{2+}$ uptake and steady-state $\left[\mathrm{Ca}^{2+}\right]_{\mathrm{i}}$ were measured as described in Methods. Cells treated with $10^{-8} \mathrm{M}$ PTH were exposed for $15 \mathrm{~min}$ in the presence or absence of $10^{-5} \mathrm{M}$ NPPB. Tracer uptake values represent means $\pm \mathrm{SE}$ of triplicate measurements performed in three experiments. ${ }^{*} P<0.01$ vs. control. ${ }^{\dagger} P<0.01$ vs. PTH.
These observations are consistent with an obligatory role of chloride channels in the mechanism of PTH-induced increases of calcium entry in distal convoluted tubule cells.

By extension, if PTH-stimulated $\mathrm{Ca}^{2+}$ influx is due to an increase in membrane voltage that has its origin in a decrease of intracellular chloride activity, then replacement of extracellular $\mathrm{Cl}^{-}$should depolarize distal convoluted tubule cells thereby preventing stimulation of calcium uptake by PTH. The finding that PTH hyperpolarized cells was illustrated in Fig. 3. We previously established that reduction of extracellular chloride depolarizes mouse distal convoluted tubule cells and inhibits ${ }^{45} \mathrm{Ca}^{2+}$ uptake (25). As hypothesized here, such membrane depolarization inhibited ${ }^{45} \mathrm{Ca}^{2+}$ uptake (Table VI) and blocked the stimulatory effect of PTH $(2.19 \pm 0.30$ vs. $2.23 \pm 0.30 \mathrm{nmol}$

Table VI. Effect of Chloride Replacement on PTH-Stimulated ${ }^{45} \mathrm{Ca}^{2+}$ Uptake

\begin{tabular}{rccc}
\hline Chloride & Valinomycin & PTH & ${ }^{45} \mathrm{Ca}^{2+}$ uptake \\
\hline$m M$ & & & nmol min $^{-1}$ mg protein \\
& & & $2.19 \pm 0.30$ \\
0 & - & + & $2.23 \pm 0.30$ \\
0 & - & - & $2.25 \pm 0.22$ \\
0 & + & + & $2.20 \pm 0.21$ \\
0 & + & - & $2.41 \pm 0.28$ \\
140 & + & + & $2.40 \pm 0.38$ \\
140 & + & & \\
\hline
\end{tabular}

${ }^{45} \mathrm{Ca}^{2+}$ uptake was measured as described in Methods. Chloride was replaced isosmotically with gluconate. For these experiments, calcium activity was adjusted by electrometric titration with a calcium electrode (Orion, Research Inc., Cambridge, MA) to be identical to that of chloride-containing solutions. The final concentration of valinomycin was $10^{-5} \mathrm{M}$ and PTH was $10^{-8} \mathrm{M}$. Values represent means $\pm \mathrm{SE}$ of triplicate measurements performed in three experiments. These studies were performed as paired measurements as part of a larger series of experiments. The observations made in the absence of PTH have been previously reported (25). 


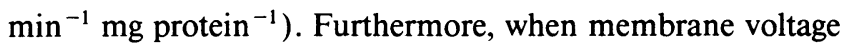
was clamped with valinomycin + potassium, the stimulatory effect of PTH on ${ }^{45} \mathrm{Ca}^{2+}$ uptake was blocked, either in the presence or absence of extracellular chloride (Table VI). These findings strongly support the view that hyperpolarization induced by PTH is an obligate step in initiating calcium entry.

\section{Discussion}

The focus of the present work was to clarify more completely the cellular events involved in the stimulatory action of PTH on calcium uptake in distal convoluted tubules. This nephron segment is the predominant site at which PTH exerts its hypocalciuric effect in rodents $(5,12)$, dogs $(31)$, and, it is thought, in humans (32). In the rabbit, homologous calcium regulatory functions are expressed in connecting tubules $(7-9,33,34)$. We were particularly interested in the effect of PTH on membrane voltage, the ionic basis of the change in voltage evoked by PTH, and the relationship between voltage and calcium entry.

For these studies we used immortalized mouse distal convoluted tubule cells. The phenotype of these cells appears similar to that of freshly isolated or primary cultures of distal convoluted tubule cells $(13,24,25)$. Results presented in Figs. 1 and 2, and in Tables I and II, establish that PTH stimulates calcium entry in these immortalized cells through dihydropyridine-sensitive calcium channels with an attendant rise of $\left[\mathrm{Ca}^{2+}\right]_{\mathrm{i}}$. These results are qualitatively and quantitatively in agreement with observations reported in freshly isolated tissue and in primary cell cultures of PTH-sensitive cortical ascending thick limbs and distal convoluted tubule cells (13). Additional evidence shows that sodium entry is mediated by $\mathrm{NaCl}$ cotransport, which is inhibitable by thiazide diuretics, and a parallel electrically conductive pathway that is blocked by amiloride $(25,35)$.

Voltage effects of PTH. Resting membrane voltage averaged $-71 \pm 2 \mathrm{mV}$. This value is entirely consistent with that measured by conventional microelectrodes in rabbit distal convoluted tubule cells of -73 to $-77 \mathrm{mV}(36,37)$. The results shown in Fig. 3 clearly demonstrate that PTH hyperpolarizes membrane voltage in mouse distal convoluted tubule cells. Previous studies of PTH effects on voltage in target distal nephron segments produced variable results. In single connecting tubules isolated from rabbit kidney and perfused in vitro, Shimizu et al. found that PTH induced biphasic changes in transepithelial voltage (22). Addition of $10^{-8} \mathrm{M}$ PTH caused an initial hyperpolarization that began after $0.5-2 \mathrm{~min}$ and peaked at $5 \mathrm{~min}$. This response was followed by spontaneous repolarization to control levels (22). Since basolateral voltage was unaffected by PTH, the observed biphasic response to PTH represents initial depolarization followed by hyperpolarization of apical membranes. When tubules were pretreated with amiloride the secondary repolarization was abolished and the time to peak hyperpolarization was lengthened to $\sim 12$ min. Our results exhibited rather different kinetics but are remarkably similar to their observations of tubules first exposed to amiloride. Two differences are apparent. First, in mouse distal convoluted tubule cells a lag of some 8-10 min occurred before a detectable change of voltage was seen. This latency is greater than that in rabbit connecting tubules where intracellular calcium begins to rise after 2 min (7). Second, in mouse distal convoluted tubule cells the hyperpolarization and the
PTH-induced elevation of $\left[\mathrm{Ca}^{2+}\right]_{i}$ were also sustained. We are still uncertain as to the origin of the pronounced latency. However, it should be noted that the latency is similar for the change in voltage as for the increase of intracellular calcium (Fig. 3, Table III) but greater than for the decrease of intracellular chloride (Fig. 4, Table III). Moreover, as we showed previously, it is comparable in isolated perfused cortical thick ascending limbs (13). Hence, the latency was not due to a basolateral diffusion barrier of cells grown on impermeant supports. The similarity in the interval between the rise of PTH-stimulated ${ }^{45} \mathrm{Ca}^{2+}$ uptake (Fig. 1 ) and the increase of $\left[\mathrm{Ca}^{2+}\right]_{\mathrm{i}}$ (Fig. 3) suggests that this delay is not referable to temporary intracellular calcium sequestration or to a stoichiometric imbalance between apical calcium entry and basolateral efflux.

The initial hyperpolarization of transepithelial voltage induced by PTH that was reported by Shimizu et al. (22) was not inhibited by amiloride but was blocked when sodium in the luminal perfusate was replaced by choline. They interpreted these observations to mean that the PTH-induced hyperpolarization was due to an increase in $\mathrm{Na}^{+}$influx across apical membranes through an amiloride-insensitive conductive pathway (22). As shown in Table I, we were unable to detect a change in ${ }^{22} \mathrm{Na}^{+}$uptake in response to stimulation with PTH for $15 \mathrm{~min}$. We also measured ${ }^{22} \mathrm{Na}^{+}$uptake at 1,2 , and 5 min after addition of $10^{-8} \mathrm{M}$ PTH but found no effect compared to untreated controls. Comparable observations have been made during in vivo and in vitro distal convoluted tubule microperfusion experiments where PTH increased calcium but not sodium absorption $(12,34,38)$. Furthermore, increased sodium entry would be expected to depolarize distal convoluted tubule cells. Therefore, we sought an alternative mechanism to account for the hyperpolarization.

Several lines of evidence support the view that PTH-induced hyperpolarization is due to activation of chloride channels, increased chloride efflux, and a reduction of intracellular chloride activity. First, under control conditions intracellular chloride can be estimated ${ }^{2}$ from the Goldman-Hodgkin-Katz equation to be $24 \mathrm{mM}$. This is comparable to the intracellular chloride activity in cortical thick ascending limb cells and rat distal convoluted tubule cells $(39,40)$. However, this value is greater than the $6 \mathrm{mM}$ calculated from the increase in SPQ fluorescence after addition of PTH or $10 \mathrm{mM}$ predicted from passive distribution at a membrane voltage of $-71 \mathrm{mV}$. Thus, under control conditions intracellular chloride activity is above its equilibrium level. Second, PTH increased the rate of iodide

2. Intracellular chloride activity, $\mathrm{Cl}_{\mathbf{i}}^{-}$, can be calculated from the Goldman-Hodgkin-Katz equation. Since sodium is distributed near equilibrium $(51,52)$ :

$$
E_{\mathrm{m}}=\frac{R T}{F} \ln \frac{C l_{\mathrm{i}}^{-}+\alpha \mathrm{K}_{\mathrm{o}}^{+}}{\mathrm{Cl}_{0}^{-}+\alpha \mathrm{K}_{\mathrm{i}}^{+}}
$$

where $R, T$, and $F$ have their usual definitions; $\mathrm{K}_{\mathrm{i}}^{+}$is the intracellular potassium concentration; $\mathrm{Cl}_{\mathrm{o}}^{-}$and $\mathrm{K}_{\mathrm{o}}^{+}$are the extracellular concentrations of chloride and potassium; and $\alpha$ is the $\mathrm{K}^{+}: \mathrm{Cl}^{-}$permeability coefficient. We estimated $\alpha$ by imposing log-fold changes in extracellular chloride or potassium and measuring the resulting change in voltage with the fluorescent dye, $\mathrm{DiOC}_{6}(3)$. Under these conditions, $\alpha=4$. $\mathrm{Cl}_{\mathrm{o}}^{-}=149 \mathrm{mM}$. Intracellular potassium, $\mathrm{K}_{\mathrm{i}}^{+}$averaged $119 \mathrm{mM}(n=6)$. $\mathrm{K}_{\mathrm{o}}^{+}=4.6$ and $E_{\mathrm{m}}=-71 \pm 2 \mathrm{mV} \cdot \mathrm{Cl}_{\mathrm{i}}^{-}$so calculated $=24 \mathrm{mM}$. This value compares favorably with that reported in rat distal convoluted tubule cells (40). 
efflux (Fig. 5) and this effect was blocked by the chloride channel blocker NPPB. These findings are consistent with the view that PTH increases chloride permeability and provides a mechanism for the decrease of intracellular chloride evoked by PTH (Fig. 4). Insofar as the change of intracellular chloride preceded both the hyperpolarization and the rise of $\left[\mathrm{Ca}^{2+}\right]_{i}$, these results suggest that the fall of intracellular chloride sets the membrane voltage. After challenge with PTH, membrane voltage hyperpolarized by $19 \mathrm{mV}$ and this effect was inhibited by NPPB (Table IV). The hyperpolarization induced by PTH would correspond to a calculated intracellular chloride activity of $5 \mathrm{mM}$ at a membrane voltage of $-90 \mathrm{mV}$. Estimates of the actual change of intracellular chloride derived from the increase in SPQ fluorescence (Fig. 4) was 6.1 $\pm 0.3 \mathrm{mM}(n=3)$, a value consistent with chloride falling to its electrochemical equilibrium level following stimulation by PTH. Moreover, intracellular $\mathrm{K}^{+}$was not affected by PTH (control $=119 \pm 9$ $\mathrm{mM}, \mathrm{PTH}=118 \pm 5 \mathrm{mM}, n=5$ ). Thus, the change of intracellular chloride activity after stimulation of distal convoluted tubule cells with PTH is sufficient to account for membrane hyperpolarization.

We propose that the primary event that occurs in response to PTH in distal convoluted tubule cells is activation of chloride channels, which results in hyperpolarization of membrane voltage. An initial increase of chloride current should first depolarize the cell. Such an effect was not observed. Shimizu et al. (22) reported that PTH depolarized basolateral membranes by $0.8 \mathrm{mV}$, but was not statistically significant. The reason for the modest depolarization may lie in the magnitude of the relative change in anion permeability after stimulation with PTH. Under control conditions $\mathrm{P}_{\mathrm{K}^{+}}: \mathrm{P}_{\mathrm{Cl}^{-}}=4^{2}$. PTH increased the rate of halide anion efflux by $128 \%$ (Fig. 5). From the Goldman-Hodgkin-Katz equation it can be calculated that an increase of chloride permeability of this magnitude would depolarize the membrane voltage by $1-2 \mathrm{mV}$. This change is too small to be detected with fluorescent dyes or conventional microelectrode techniques.

We argue herein that PTH hyperpolarizes distal convoluted tubule cells by increasing the chloride diffusion potential across basolateral plasma membranes, the site of chloride channels in distal convoluted tubule cells $(36,37$; Dietl, Stanton, and Friedman, unpublished observations). An increased chloride diffusion potential also accounts for the hyperpolarization induced by thiazide diuretics in distal convoluted tubule cells (25) and that evoked by furosemide in cortical thick ascending limbs (41). However, there is an additional and perhaps subtle difference between the means by which a change in $\mathrm{E}_{\mathrm{Cl}^{-}}$, the Nernst equilibrium potential for chloride, arises after treatment with PTH or thiazide diuretics. In the case of thiazide diuretics, chloride entry by the apical membrane $\mathrm{NaCl}$ cotransporter is blocked. Continued chloride efflux through NPPBsensitive channels results in a drop of intracellular chloride, which in turn hyperpolarizes the cell membrane (25). PTH, on the other hand, does not change the rate of $\mathrm{NaCl}$ entry (Table I). In the case of PTH, we propose that basolateral chloride channels are activated by a mechanism involving phosphorylation by protein kinase A and/or protein kinase C. PTH has been shown to activate chloride channels in proximal tubule cells (42) and in bone (43). In proximal tubule cells, both protein kinase $A$ and protein kinase $C$ may activate chloride channels after stimulation with PTH (42). Chloride channels in other transporting epithelial cells are also regulated by protein kinase $A$ or by protein kinase $C(30,44-47)$.

Our findings provide an alternate explanation for the results reported by Shimizu et al. (22). Two apical membrane sodium entry mechanisms are present in rabbit connecting tubule cells and in mouse distal convoluted tubule cells: an amiloride-sensitive $\mathrm{Na}^{+}$channel and thiazide-inhibitable, electroneutral $\mathrm{NaCl}$ cotransport $(33,35,48)$. Amiloride had no effect on PTH-induced hyperpolarization of apical plasma membranes (22), presumably because chloride entry occurs through the electroneutral $\mathrm{NaCl}$ cotransporter and exits through a basolateral chloride channel. Replacement of luminal sodium with choline would have prevented cation entry through both pathways. By inhibiting $\mathrm{Na}^{+}$-coupled $\mathrm{Cl}^{-}$transport, chloride entry is blocked, leading to a fall of intracellular chloride and membrane hyperpolarization. Thus, we propose that the origin of the PTH-induced membrane hyperpolarization is similar in rabbit connecting tubules and in mouse distal convoluted tubules.

Relationship between membrane voltage and PTH-stimulated calcium entry. The results presented and discussed thus far show that PTH hyperpolarizes membrane voltage and that this hyperpolarization involves activation of chloride channels. For these events to have physiological relevance, calcium entry would have to be governed by membrane voltage. In other words, according to the mechanism we propose, the stimulatory action of PTH requires that the induced hyperpolarization increase calcium entry by distal convoluted tubule cells. The data in support of this argument are shown in Tables V and VI. First, preventing PTH-induced hyperpolarization with the chloride channel blocker NPPB abolished the stimulatory effect on ${ }^{45} \mathrm{Ca}^{2+}$ uptake and on $\left[\mathrm{Ca}^{2+}\right]_{\mathrm{i}}($ Table V). Second, depolarizing membrane voltage by chloride replacement completely inhibited the stimulatory effect of PTH on ${ }^{45} \mathrm{Ca}^{2+}$ uptake (Table VI). Third, clamping the membrane voltage with valinomycin blocked the inhibitory effect of chloride removal on ${ }^{45} \mathrm{Ca}^{2+}$ uptake (Table VI). Fourth, clamping the membrane voltage with valinomycin in the presence of normal extracellular chloride blocked the stimulatory effect of PTH on ${ }^{45} \mathrm{Ca}^{2+}$ uptake (Table VI). Finally, we previously established that directly manipulating the membrane voltage by varying extracellular potassium caused proportionate changes in ${ }^{45} \mathrm{Ca}^{2+}$ uptake (25). Thus, hyperpolarizing the membrane voltage stimulated ${ }^{45} \mathrm{Ca}^{2+}$ uptake whereas depolarizing the membrane reduced it. Taken together, the present results permit a tentative model for stimulation of calcium entry by PTH to be developed. According to this model, PTH hyperpolarizes distal convoluted tubule cells. Membrane hyperpolarization, in turn, leads to an increase of calcium entry through calcium channels that are modulated by dihydropyridine-type calcium channel agonists and antagonists (25). This model for voltage-dependent, receptoroperated calcium channels is fundamentally similar to the mechanism of stimulation of calcium entry by secretagogues in mast cells (15). In those studies, calcium influx was increased during membrane hyperpolarization. Furthermore, activation of a chloride current was responsible for the membrane hyperpolarization (49).

Calcium and sodium absorption in the kidney normally proceed in parallel. However, certain physiological, pharmacological, or pathological influences are known to dissociate one from the other. PTH, for instance, reduces renal calcium excre- 
tion without a change in sodium excretion $(10,12,38)$. Although the mechanisms responsible for the dissociation are not known definitively, they all proceed in distal convoluted tubules. It has been suggested that in a variety of epithelial cells, sodium entry across apical plasma membranes may be regulated by a feedback mechanism involving intracellular calcium with increases of intracellular calcium activity inhibiting sodium influx (50). Were such a mechanism present in distal convoluted tubule cells it would be expected to amplify the dissociation of calcium and sodium transport induced by PTH. In particular, the stimulation of calcium entry with an attendant rise of $\left[\mathrm{Ca}^{2+}\right]_{\mathrm{i}}$ might inhibit sodium influx through electrically conductive or electroneutral pathways. However, the data in Table I show that PTH had no detectable effect on sodium uptake. Thus, such a negative feedback mechanism would not appear to be involved in the regulation of sodium entry in distal convoluted tubules. However, it is possible that other physiological, pharmacological, or pathological maneuvers that evoke a greater elevation of $\left[\mathrm{Ca}^{2+}\right]_{i}$ than does $10^{-8} \mathrm{M}$ PTH, might participate in negative feedback regulation of sodium entry.

In summary, our results show that PTH increases the rate of calcium, but not of sodium, uptake by mouse distal convoluted tubule cells. Increased calcium uptake by PTH results in concentration-dependent elevations of intracellular calcium activity. PTH also enhanced electrically conductive halide anion permeability, increased chloride efflux, and decreased intracellular chloride activity. The decrease of intracellular chloride activity was responsible for membrane hyperpolarization that in turn stimulated calcium entry. Application of the chloride channel blocker NPPB prevented the PTH effect on voltage, as well as the stimulatory effect of PTH on calcium uptake. PTHstimulated calcium entry is mediated by dihydropyridine-inhibitable calcium channels. The increased chloride conductance evoked by PTH, in combination with stimulation of calcium entry through dihydropyridine sensitive calcium channels, provides the means of increasing the driving force for regulated calcium entry in calcium-transporting distal convoluted tubule cells.

\section{Acknowledgments}

The excellent technical assistance of Ms. B. Coutermarsh is greatly appreciated. The authors also thank Mr. Charles Fanghella and the Nikon Corp. for support and loans of equipment, and Dr. Bruce Stanton for helpful suggestions with the manuscript.

These studies were supported by National Institutes of Health grant GM-34399. F. A. Gesek received support from National Institutes of Health grant DK-07301.

\section{References}

1. Bourdeau, J. E., and M. B. Burg. 1980. Effect of PTH on calcium transport across the cortical thick ascending limb of Henle's loop. Am. J. Physiol. 239:F121-F126.

2. Suki, W. N., D. Rouse, R. C. K. Ng, and J. P. Kokko. 1980. Calcium transport in the thick ascending limb of Henle. Heterogeneity of function in the medullary and cortical segments. J. Clin. Invest. 66:1004-1009.

3. Friedman, P. A. 1988. Basal and hormone-activated calcium absorption in mouse renal thick ascending limbs. Am. J. Physiol. 254:F62-F70.

4. Imai, M. 1981. Effects of parathyroid hormone and $\mathrm{N}^{6}, \mathrm{O}^{2}$-dibutyryl cyclic AMP on calcium transport across the rabbit distal nephron segments perfused in vitro. Pfluegers Arch. Eur. J. Physiol. 390:145-151.

5. Greger, R., F. Lang, and H. Oberleithner. 1978. Distal site of calcium reabsorption in the rat nephron. Pfluegers Arch. Eur. J. Physiol. 374:153-157.
6. Malnic, G., R. M. Klose, and G. Giebisch. 1966. Microperfusion study of distal tubular potassium and sodium transfer in rat kidney. Am. J. Physiol. 211:548-559.

7. Bourdeau,'J. E., and K. Lau. 1989. Effects of parathyroid hormone on cytosolic free calcium concentration in individual rabbit connecting tubules. $J$. Clin. Invest. 83:373-379.

8. Shimizu, T., K. Yoshitomi, M. Nakamura, and M. Imai. 1990. Effects of PTH, calcitonin, and cAMP on calcium transport in rabbit distal nephron segments. Am. J. Physiol. 259:F408-F414.

9. Bindels, R. J. M., A. Hartog, J. Timmermans, and C. H. van Os. 1991. Active $\mathrm{Ca}^{2+}$ transport in primary cultures of rabbit kidney $\mathrm{CCD}$ : stimulation by 1,25-dihydroxyvitamin $\mathrm{D}_{3}$ and PTH. Am. J. Physiol. 261:F799-F807.

10. Bourdeau, J. E. 1983. Renal handling of calcium. In Divalent Ion Homeostasis. B. M. Brenner and J. H. Stein, editors. Churchill Livingstone, Inc., New York. 1-31.

11. Friedman, P. A. 1988. Renal calcium transport: sites and insights. News Physiol. Sci. 3:17-21.

12. Costanzo, L. S., and E. E. Windhager. 1980. Effects of PTH, ADH, and cyclic AMP on distal tubular $\mathrm{Ca}$ and Na reabsorption. Am. J. Physiol. 239:F478F485.

13. Bacskai, B. J., and P. A. Friedman. 1990. Activation of latent $\mathrm{Ca}^{2+}$ channels in renal epithelial cells by parathyroid hormone. Nature (Lond.). 347:388391.

14. Tsien, R. W., P. T. Ellinor, and W. A. Horne. 1991. Molecular diversity of voltage-dependent $\mathrm{Ca}^{2+}$ channels. Trends Pharmacol. Sci. 12:349-354.

15. Matthews, G., E. Neher, and R. Penner. 1989. Second messenger-activated calcium influx in rat peritoneal mast cells. J. Physiol. (Lond.). 418:105130.

16. Di Virgilio, F., P. D. Lew, T. Andersson, and T. Pozzan. 1987. Plasma membrane potential modulates chemotactic peptide-stimulated cytosolic free $\mathrm{Ca}^{2+}$ changes in human neutrophils. J. Biol. Chem. 262:4574-4579.

17. Sarkadi, B., A. Tordai, and G. Gardos. 1990. Membrane depolarization selectively inhibits receptor-operated calcium channels in human T (Jurkat) lymphoblasts. Biochim. Biophys. Acta. 1027:130-140.

18. Oettgen, H. C., C. Terhorst, L. C. Cantley, and P. M. Rosoff. 1985. Stimulation of the T3-T cell receptor complex induces a membrane-potential-sensitive calcium influx. Cell. 40:583-590.

19. Savage, A. L., M. Biffen, and B. R. Martin. 1989. Vasopressin-stimulated $\mathrm{Ca}^{2+}$ influx in rat hepatocytes is inhibited in high- $\mathrm{K}^{+}$medium. Biochem. J. 260:821-827.

20. Lückhoff, A., and D. E. Clapham. 1992. Inositol 1,3,4,5-tetrakisphosphate activates an endothelial $\mathrm{Ca}^{2+}$-permeable channel. Nature (Lond.). 355:356-358.

21. Wittner, M., and A. Di Stefano. 1990. Effects of antidiuretic hormone, parathyroid hormone and glucagon on transepithelial voltage and resistance of the cortical and medullary thick ascending limb of Henle's loop of the mouse nephron. Pfluegers Arch. Eur. J. Physiol. 415:707-712.

22. Shimizu, T., K. Yoshitomi, M. Nakamura, and M. Imai. 1990. Effect of parathyroid hormone on the connecting tubule from the rabbit kidney: biphasic response of transmural voltage. Pfluegers Arch. Eur. J. Physiol. 416:254-261.

23. Pizzonia, J. H., F. A. Gesek, S. M. Kennedy, B. A. Coutermarsh, B. J. Bacskai, and P. A. Friedman. 1991. Immunomagnetic separation, primary culture and characterization of cortical thick ascending limb plus distal convoluted tubule cells from mouse kidney. In Vitro Cell. \& Dev. Biol. 27A:409-416.

24. Friedman, P. A., B. A. Coutermarsh, J. S. Rhim, and F. A. Gesek. 1991. Characterization of immortalized mouse distal convoluted tubule cells. J. Am. Soc. Nephrol. 2:737. (Abstr.)

25. Gesek, F. A., and P. A. Friedman. 1992. Mechanism of calcium transport stimulated by chlorothiazide in mouse distal convoluted tubule cells. J. Clin. Invest. 90:429-438.

26. Verkman, A. S. 1990. Development and biological applications of chloride-sensitive fluorescent indicators. Am. J. Physiol. 259:C375-C388.

27. Zeidel, M. L., D. Kikeri, P. Silva, M. Burrowes, and B. M. Brenner. 1988. Atrial natriuretic peptides inhibit conductive sodium uptake by rabbit inner medullary collecting duct cells. J. Clin. Invest. 82:1067-1074.

28. Lowry, O. H., N. J. Rosebrough, A. L. Farr, and R. J. Randall. 1951. Protein measurement with the Folin phenol reagent. J. Biol. Chem. 193:265275.

29. Clancy, J. P., J. D. McCann, M. Li, and M. J. Welsh. 1990. Calcium-dependent regulation of airway epithelial chloride channels. Am. J. Physiol. 258:L25-L32.

30. Tabcharani, J. A., X-B. Chang, J. R. Riordan, and J. W. Hanrahan. 1991. Phosphorylation-regulated $\mathrm{Cl}^{-}$channel in $\mathrm{CHO}$ cells stably expressing the cystic fibrosis gene. Nature (Lond.). 352:628-631.

31. Sutton, R. A. L., N. L. M. Wong, and J. H. Dirks. 1976. Effects of parathyroid hormone on sodium and calcium transport in the dog nephron. Clin. Sci. Mol. Med. 51:345-351.

32. Chabardès, D., M. Gagnon-Brunette, M. Imbert-Teboul, O. Gontcharevskaia, M. Montégut, A. Clique, and F. Morel. 1980. Adenylate cyclase responsive- 
ness to hormones in various portions of the human nephron. J. Clin. Invest. 65:439-448.

33. Shimizu, T., M. Nakamura, K. Yoshitomi, and M. Imai. 1991. Interaction of trichlormethiazide or amiloride with PTH in stimulating calcium absorption in the rabbit connecting tubule. Am. J. Physiol. 261:F36-F43.

34. Shareghi, G. R., and L. C. Stoner. 1978. Calcium transport across segments of the rabbit distal nephron in vitro. Am. J. Physiol. 235:F367-F375.

35. Gesek, F. A., B. A. Coutermarsh, and P. A. Friedman. 1991. Thiazide and amiloride-sensitive $\mathrm{Na}^{+}$uptake mechanisms in distal convoluted tubule cells. $J$. Am. Soc. Nephrol. 2:737. (Abstr.)

36. Velázquez, H., and R. Greger. 1985. $\mathrm{K} \& \mathrm{Cl}$ permeabilities in cells of rabbit early distal convoluted tubule. Kidney Int. 27:322. (Abstr.)

37. Yoshitomi, K., T. Shimizu, J. Taniguchi, and M. Imai. 1989. Electrophysiological characterization of rabbit distal convoluted tubule cell. Pfluegers Arch. Eur. J. Physiol. 414:457-463.

38. Harris, C. A., M. A. Burnatowska, J. F. Seely, R. A. L. Sutton, G. A Quamme, and J. H. Dirks. 1979. Effects of parathyroid hormone on electrolyte transport in the hamster nephron. Am. J. Physiol. 236:F342-F348.

39. Lafond, J., M. Leclerc, and M. G. Brunette. 1991. Characterization of calcium transport by basal plasma membranes from human placental syncytiotrophoblast. J. Cell. Physiol. 148:17-23.

40. Beck, F.-X., A. Dörge, R. Rick, M. Schramm, and K. Thurau. 1987. Effect of potasium adaptation on the distribution of potassium, sodium and chloride across the apical membrane of renal tubular cells. Pfluegers Arch. Eur. J. Physiol. 409:477-485.

41. Wittner, M., A. Di Stefano, P. Wangemann, and R. Greger. 1991. How do loop diuretics act? Drugs. 41 (Suppl. 3):1-13.

42. Suzuki, M., T. Morita, K. Hanaoka, Y. Kawaguchi, and O. Sakai. 1991. A $\mathrm{Cl}^{-}$channel activated by parathyroid hormone in rabbit renal proximal tubule cells. J. Clin. Invest. 88:735-742.
43. Chesnoy-Marchais, D., and J. Fritsch. 1989. Chloride current activated by cyclic AMP and parathyroid hormone in rat osteoblasts. Pfluegers Arch. Eur. J. Physiol. 415:105-114.

44. Schwiebert, E. M., K. H. Karlson, P. A. Friedman, P. Dietl, W. S. Spielman, and B. A. Stanton. 1992. Adenosine regulates a chloride channel via protein kinase $\mathrm{C}$ and a G-protein in a rabbit cortical collecting duct cell line. J. Clin. Invest. 89:834-841.

45. Anderson, M. P., and M. J. Welsh. 1991. Calcium and cAMP activate different chloride channels in the apical membrane of normal and cystic fibrosis epithelia. Proc. Natl. Acad. Sci. USA. 88:6003-6007.

46. Cheng, S. H., D. P. Rich, J. Marshall, R. J. Gregory, M. J. Welsh, and A. E. Smith. 1991. Phosphorylation of the R domain by cAMP-dependent protein kinase regulates the CFTR chloride channel. Cell. 66:1027-1036.

47. Rogers, K. V., P. S. Goldman, R. A. Frizzell, and G. S. McKnight. 1990 Regulation of $\mathrm{Cl}^{-}$transport in T84 cell clones expressing a mutant regulatory subunit of cAMP-dependent kinase. Proc. Natl. Acad. Sci. USA. 87:8975-8979.

48. Shimizu, T., K. Yoshitomi, M. Nakamura, and M. Imai. 1988. Site and mechanism of action of trichlormethiazide in rabbit distal nephron segments perfused in vitro. J. Clin. Invest. 82:721-730.

49. Matthews, G., E. Neher, and R. Penner. 1989. Chloride conductance activated by external agonists and internal messengers in rat peritoneal mast cells. J. Physiol. (Lond.). 418:131-144.

50. Taylor, A., and E. E. Windhager. 1985. Cytosolic calcium and its role in the regulation of transepithelial ion and water transport. In The Kidney: Physiology and Pathophysiology. D. W. Seldin and G. Giebisch, editors. Raven Press, Ltd., New York. 1297-1322.

51. Gesek, F. A. 1992. $\alpha_{2}$-Adrenoceptors stimulate $\mathrm{Na}^{+}$uptake in distal convoluted tubule cells. FASEB (Fed. Am. Soc. Exp. Biol.) J. 6:A1808. (Abstr.)

52. Schultz, S. G. 1980. Basic Principles of Membrane Transport. Cambridge University Press, Cambridge, UK. 1-144. 